\title{
Agreement between parents and adolescents on dental fluorosis: a population-based study
}

\author{
Maria Eneide Leitão de Almeida ${ }^{(a)}$ \\ Ana Karine Macedo Teixeira(b) \\ Carlos Henrique Alencar ${ }^{(c)}$ \\ Saul Martins Paiva(d) \\ Mauro Henrique Nogueira \\ Guimarães de Abreu ${ }^{(e)}$
}

\footnotetext{
(a) Department of Dental Clinics, School of Pharmacy, Dentistry and Nursery, Univ Federal do Ceará - UFC, Fortaleza, CE, Brazil.

(b) Department of Dental Clinics, School of Dentistry, Univ Federal do Ceará - UFC, Sobral, CE, Brazil.

(c) Swiss Tropical and Public Health Institute, Univ of Basel, Basel, Switzerland.

(d) Department of Pediatric Dentistry and Orthodontics, School of Dentistry, Univ Federal de Minas Gerais - UFMG, Belo Horizonte, MG, Brazil.

(e) Departament of Community and Preventive Dentistry, School of Dentistry, Univ Federal de Minas Gerais - UFMG, Belo Horizonte, MG, Brazil.
}

Declaration of Interests: The authors certify that they have no commercial or associative interest that represents a conflict of interest in connection with the manuscript.

Corresponding Author:

Mauro Henrique Nogueira

Guimarães de Abreu

E-mail: maurohenriqueabreu@ig.com.br

Submitted: Aug 27, 2012

Accepted for publication: Jan 10, 2013

Last revision: Jan 14, 2013

\begin{abstract}
This study evaluated the prevalence and severity of dental fluorosis and compared the reports from adolescents aged 12 to 18 years with those of their parents regarding the perceptions and concerns arising from this disease. The study was conducted in the cities of Viçosa and Sobral and the District of Rafael Arruda (Sobral), Ceará. A crosssectional study was conducted from October 2010 to March 2011, with 891 students examined and 780 parents or guardians interviewed. Dental fluorosis was measured using the Dean's Index, and the Child's and Parent's Questionnaire about Teeth Appearance was used to assess the reports from parents and adolescents. A chi-squared test for trends was used to compare the opinions of parents and adolescents about fluorosis, and the agreement was measured using the weighted kappa. For the dichotomous variables, we used the unweighted kappa coefficient. The prevalence of fluorosis was 29.7\%, but in the District of Rafael Arruda, evidence of very mild and mild fluorosis was found in $32.5 \%$ of the subjects, and moderate and severe fluorosis was found in $28.7 \%$. There was poor agreement between the data reported by the adolescents and their parents or guardians regarding areas of concern and their perceived satisfaction with the appearance and color of their teeth. The prevalence of dental fluorosis was high in one of the communities studied, but the clinical diagnosis of this condition should not necessarily equate with concern and dissatisfaction with aesthetic appearances among teenagers and their parents.
\end{abstract}

Descriptors: Fluorosis, Dental; Diagnostic Self Evaluation; Epidemiology.

\section{Introduction}

Fluoride use is considered to be the best strategy for controlling dental caries in communities or individuals, although there is some disagreement over the use of fluoride and the occurrence of fluorosis. Thus, balancing the benefits and risks of fluoride remains a constant challenge. Nevertheless, in every country that has experienced the decreased prevalence of cavities over the last few decades, fluoride was (or is still being) used. ${ }^{1}$

Few studies have extended beyond normative diagnosis to include other subjective measurements of the impact of fluorosis. ${ }^{2,3}$ Thus, expanded investigations that incorporate individuals' opinions about their own health conditions have been important to improve the understand- 
ing of the occurrence of diseases. ${ }^{4-6}$ It is important to investigate community perceptions and dissatisfaction levels regarding dental fluorosis because the value assigned by the community to a health problem can make it a public health priority. ${ }^{711}$ In Brazil, few studies have used validated instruments to assess the correlation between parents and teens regarding their perceptions and concerns about dental fluorosis. Recently, an instrument for this purpose was validated in Brazil. ${ }^{12}$ Thus, it is important to assess this correlation because parents play important roles in the health of their teenagers.

This study aimed to evaluate the prevalence and severity of dental fluorosis and the agreement between the reports of adolescents aged 12 to 18 years old and those of their parents regarding the perceptions and concerns arising from this disease.

\section{Methodology}

This study was approved by the Human Research Ethics Committee of the Universidade Federal do Ceará, Brazil. An urban area encompassing two towns in the State of Ceará were intentionally selected:

- Viçosa do Ceará, because the fluoride levels in its public water supplies are considered optimal (0.62 ppm F); and

- the city of Sobral, which has fluoride concentrations below the recommended levels (0.44 ppm F).

The district of Rafael Arruda, which is located in the city of Sobral, was also selected because endemic fluorosis occurs there as the result of an excess of natural fluoride in its water sources.

This cross-sectional study involving $12-$ to 18 -year-old school students was undertaken from October 2010 to March 2011. We sampled students who were enrolled in local schools in the study locations and who were born in and resided in these towns. The students, together with their parents or guardians, agreed to participate in this research. The following exclusion criteria were applied for the adolescents:

- anterior edentulism,

- using braces or other prostheses, and

- studying at night.
We excluded adolescents who studied at night because the oral exam was performed under natural light. The sample size was defined to meet a sampling error of $5 \%$ and a confidence level of $95 \%$. Ten percent was added to the sample size to compensate for non-permanent residents of the sample, for a total of 780 pairs of adolescents and their parents or guardians. However, the final sample included 891 adolescents, to compensate for possible losses in returning the forms. Taking into account that the district of Rafael Arruda had 900 adolescents and using the correction for the finite universe, the sample ultimately consisted of 218 people. In Sobral, there were 25,491 subjects, and the final sample was 285 participants. In Viçosa, there were 8,750 subjects, resulting in a final sample of 279 students. The sampling units were identified by applying the technique of systematic random sampling. The selection of schools was undertaken by weighted random sampling, according to the SB Brazil 2003 manual, which prescribes the random selection of 20 schools per town. For the locations that operated up to 20 schools, all of the schools participated in the sample. This situation was found in Viçosa do Ceará (9 schools) and in the district of Rafael Arruda (one school). Of the 38 schools in Sobral, 20 were randomly selected; however, only 15 schools participated in the study because some of the schools could not be contacted. In addition, the schools with fewer than 10 students in the study age group and those schools that did not provide authorization were excluded as well.

Dental fluorosis was measured using Dean's Index. The examinations were performed by eight previously trained and calibrated examiners who used dental mirrors and periodontal probes from the World Health Organization under natural light. Each adolescent was examined in a chair at the school. Dental students performed the exams. The calibration of the examiners followed the recommendation of SB Brazil 2003..$^{13}$ All of the teeth were examined, and the dental records of the two teeth most affected by fluorosis were considered. For inter-examiner agreement, Cohen's kappa value was greater than 0.82 , and the intra-examiner value was greater than 0.62 . In this study, fluorosis was cat- 
egorized into three levels:

- the absence of fluorosis (codes 0 and 1 ),

- very mild and mild fluorosis (codes 2 and 3), and

- moderate and severe fluorosis (codes 4 and 5). ${ }^{14}$

We used the Child's and Parent's Questionnaire about Teeth Appearance, which aims to measure the concerns of parents and children regarding their perceptions about dental appearance, including problems related to dental fluorosis. ${ }^{7}$ This instrument was translated and adapted to the Brazilian context, and the validation results showed intraclass correlation coefficients greater than 0.60 . The questionnaire includes questions about physical, psychological, and social conditions beyond the topics of perceptions of color and other aesthetic conditions related to the teeth. The response options for the five items and sub-items were presented in the form of multiple choices. The first three items investigate how the child has felt over the past two months and whether he or she has felt uncomfortable, concerned or has been prevented from smiling because of the appearance of his or her teeth, according to the views of his or her parents/guardians and himself or herself. ${ }^{12}$

To compare fluorosis in the opinions of the parents and adolescents, the chi-squared test of linear trends was performed. To analyze the degree of agreement between the adolescents and their parents or guardians, the weighted kappa was used for ordinal categorical variables, and the unweighted kappa coefficient was used for dichotomous variables.

\section{Results}

We examined 891 students, and 780 parents or guardians were interviewed, for a total of 1,671 individuals. It was observed that $29.7 \%$ of the adolescents were affected by varying levels of fluorosis. For the results regarding prevalence, 891 individuals were analyzed. For the results regarding agreement between the parents and adolescents, the sample included 780 pairs of students and parents or guardians.

In the district of Rafael Arruda, only $38.8 \%$ of the 237 adolescents examined had no fluorosis. In the urban area of Sobral and Viçosa, the rates were $69.8 \%$ and $91.6 \%$, respectively (Table 1 ).

The diagnosis of fluorosis was not significantly associated with the self-reported assessments of the students about the color of their teeth. A significant association was found in Rafael Arruda between the parents' opinions of the evaluation of the appearance of their children's teeth and the clinical diagnosis of fluorosis (Table 2).

The degree of concordance between the information reported by the adolescents and that reported

Table 1 - Prevalence of fluorosis in Rafael Arruda, Viçosa and Sobral, Ceará, 2010-2011.

\begin{tabular}{c|c|c|r|r|r|r}
\hline \multirow{2}{*}{$\begin{array}{c}\text { Dean's } \\
\text { index }\end{array}$} & \multicolumn{2}{|c|}{$\begin{array}{c}\text { Sobral } \\
\text { (Rafael Arruda) }\end{array}$} & \multicolumn{2}{c|}{$\begin{array}{c}\text { Sobral } \\
\text { (urban area) }\end{array}$} & \multicolumn{2}{c}{$\begin{array}{c}\text { Viçosa } \\
\text { (urban area) }\end{array}$} \\
\cline { 2 - 7 } & $\mathrm{n}$ & $\%$ & \multicolumn{1}{c|}{$\mathrm{n}$} & \multicolumn{1}{c}{$\%$} & \multicolumn{1}{c}{$\mathrm{n}$} & $\%$ \\
\hline 0 to 1 & 92 & 38.8 & 206 & 69.8 & 329 & 91.6 \\
\hline 2 to 3 & 77 & 32.5 & 87 & 29.5 & 28 & 7.8 \\
\hline 4 to 5 & 68 & 28.7 & 2 & 0.7 & 2 & 0.6 \\
\hline Total & 237 & 100.0 & 295 & 100.0 & 359 & 100.0 \\
\hline
\end{tabular}

Table 2 - Degree of agreement according to adolescents and their parents or guardians about dissatisfaction with tooth conditions in Rafael Arruda, Sobral and Viçosa, Ceará, 2010-2011.

\begin{tabular}{c|c|c|c|c|c|c|}
\hline \multirow{2}{*}{$\begin{array}{c}\text { Dean's } \\
\text { index }\end{array}$} & \multicolumn{3}{|c|}{$\begin{array}{c}\text { Percentage of adolescents who do } \\
\text { not consider their own teeth } \\
\text { nice and pretty (\%) }\end{array}$} & \multicolumn{3}{|c|}{$\begin{array}{c}\text { Percentage of parents or guardians } \\
\text { who do not consider the teeth of their } \\
\text { respective adolescents nice and pretty (\%) }\end{array}$} \\
\cline { 2 - 8 } & $\begin{array}{c}\text { Sobral } \\
\text { (Rafael } \\
\text { Arruda) }\end{array}$ & $\begin{array}{c}\text { Sobral } \\
\text { (urban } \\
\text { area) }\end{array}$ & $\begin{array}{c}\text { Viçosa } \\
\text { (urban } \\
\text { area) }\end{array}$ & $\begin{array}{c}\text { Sobral } \\
\text { (Rafael }\end{array}$ & $\begin{array}{c}\text { Sobral } \\
\text { (urban } \\
\text { area) }\end{array}$ & $\begin{array}{c}\text { Viçosa } \\
\text { (urban } \\
\text { area) }\end{array}$ \\
\hline 0 to 1 & 16.3 & 16.2 & 29.6 & 35.3 & 23.7 & 27.9 \\
\hline 2 to 3 & 19.7 & 16.7 & 28.6 & 38.6 & 28.9 & 20.8 \\
\hline 4 to 5 & 22.1 & 50.0 & 50.0 & 55.4 & 0.0 & 27.4 \\
\hline$p$ value* & 0.354 & 0.644 & 0.847 & 0.016 & 0.577 & 0.456 \\
\hline
\end{tabular}

${ }^{*}$ Chi-squared trend test. 
Table 3 - Agreement between parents and adolescents in Rafael Arruda, Sobral and Viçosa, Ceará, 2010-2011.

\begin{tabular}{|c|c|c|}
\hline Item & $\begin{array}{l}\text { Kappa coefficient } \\
(\mathrm{Cl} 95 \%)^{\ddagger}\end{array}$ & $\begin{array}{c}\text { Raw } \\
\text { concordance }\end{array}$ \\
\hline $\begin{array}{l}\text { Appearance bothers } \\
\text { respondent }\end{array}$ & $0.22(0.16-0.27)^{*}$ & 0.30 \\
\hline $\begin{array}{l}\text { Appearance concerns } \\
\text { respondent }\end{array}$ & $0.16(0.10-0.21)^{*}$ & 0.28 \\
\hline $\begin{array}{l}\text { Appearance caused the } \\
\text { adolescent to stop smiling }\end{array}$ & $0.34(0.29-0.40)^{*}$ & 0.41 \\
\hline Dissatisfaction with teeth & $0.29(0.24-0.33)^{*}$ & 0.41 \\
\hline Concern with teeth & $0.29(0.21-0.37)^{\dagger}$ & 0.71 \\
\hline Alignment & $0.38(0.33-0.43)^{*}$ & 0.46 \\
\hline Concern with alignment & $0.34(0.26-0.40)^{\dagger}$ & 0.70 \\
\hline Discoloration & $0.32(0.27-0.37)^{*}$ & 0.47 \\
\hline Concern with discoloration & $0.27(0.19-0.35)^{\dagger}$ & 0.71 \\
\hline Health of teeth & $0.29(0.24-0.34)^{*}$ & 0.45 \\
\hline $\begin{array}{l}\text { Concern for } \\
\text { health of teeth }\end{array}$ & $0.30(0.22-0.38)^{\dagger}$ & 0.71 \\
\hline $\begin{array}{l}\text { Color of teeth } \\
\text { nice and pretty }\end{array}$ & $0.19(0.14-0.23)^{*}$ & 0.39 \\
\hline
\end{tabular}

*Weighed kappa; †Cohen's kappa; $\neq p$ value $<0.001$.

by their parents or guardians regarding areas of concern, perception of appearance and satisfaction with tooth color ranged from poor to weak (Table 3).

\section{Discussion}

The prevalence of dental fluorosis found for the cities of Viçosa and Sobral was greater than the average found in the State of Ceará, which was $2.47 \%$ at 12 years old and $0.95 \%$ among adolescents. ${ }^{15}$ The rate in Sobral was higher than expected because this city has fluoride levels that are lower than the average recommended level. ${ }^{2}$ However, the severity of injuries in both Sobral and Viçosa was low. Changes in the concentrations of fluoride could explain this finding. ${ }^{16}$ Although there was no evidence of significant changes in the concentration of fluoride in any of these communities, further studies are needed in these communities.

The district of Rafael Arruda had a high prevalence and severity of dental fluorosis. This finding demonstrated the occurrence of endemic fluorosis, which indicated that this town was worthy of continuous research and health surveillance activities to monitor this disease. The defluoridation of water supplies and the aesthetic treatment of this disease should be performed by competent state and municipal governments. The community must also participate.

The dental fluorosis rates in Sobral and Rafael Arruda were greater than the results of a Brazilian survey, which revealed a $16.7 \%$ prevalence in 12 -year-old children in the entire population and $14.5 \%$ in the Northeastern population. The rate of severe fluorosis might be considered unimportant. ${ }^{17}$ However, there has been wide variation in the fluorosis measurement methods that have been used in several studies published in different regions of Brazil and in other countries, as well as differences in the age groups studied and variability among regions; the fluorosis rates ranged from $18 \%$ to $80 \% .^{3,5,9,18-26}$ Thus, it is difficult to compare results because of the diversity of the indices used for dental fluorosis. ${ }^{27}$

The clinical diagnosis of fluorosis was not significantly associated with the self-reported assessments of the students who were interviewed about the color of their teeth, and there was no significant agreement between the parents from the cities of Viçosa and Sobral. However, Rafael Arruda, where the amount of aesthetic damage caused by fluorosis was more severe, this association was significant for parents but not for their children, demonstrating that parents and children have different interpretations regarding satisfaction with tooth color. Several studies have confirmed these findings and have shown that fluorosis is not a significant factor in dissatisfaction with tooth appearance and color or with aesthetic appearance changes that are caused by fluorotic spots. ${ }^{5-10,20,22,28}$ Note that the diagnosis of fluorosis using Dean's Index accounts for the two worse conditions found in the dental arch. As the visualization of fluorosis is easier in the anterior teeth, for the general public, it is suggested that this fact is a complicating factor in the self-assessment of fluorosis.

A survey conducted in Canada compared the satisfaction of dentists, parents and children regarding the color of the teeth of the children. The children were more critical about the color of their 
teeth compared to the parents and dentists, and girls were more critical than boys. However, fluorosis, in general, was not perceived by parents and children as an important aesthetic problem. ${ }^{29}$ Our study results were different from those of a Canadian study, most likely because the severity of dental fluorosis in Rafael Arruda differed from that reported in the Canadian study. As observed in the present study, there seems to be difficulty in verifying the different degrees of fluorosis and in determining how fluorosis affects the dental aesthetics of parents and children, and this difficulty increases when comparing the perspectives of dentists. Hence, it is important to have a dialogue among all parties to reach a consensus regarding the treatment of the disease.

Another study revealed no changes in the perceptions of parents regarding the color of the teeth of their children after major changes in the prevalence and severity of fluorosis. ${ }^{30}$

Despite its raw concordance, the agreement between parents and adolescents ranged from poor to weak. This finding suggests that an individual's perception of his or her oral health seems to be related to morphological features of the teeth, and an individual's response to his or her oral condition can

\section{References}

1. Tenuta LMA, Cury JA. Fluoride: its role in dentistry. Braz Oral Res. 2010;24 Suppl 1:9-17.

2. Alkhatib M, Holt R, Bedi R. Aesthetically objectionable fluorosis in the United Kingdom. Br Dent J. 2004 Sep;197(6):3258.

3. Michel-Crosato E, Biazevic MGH, Crosato E. Relationship between dental fluorosis and quality of life: a population based study. Braz Oral Res. 2005 Apr-Jun;19(2):150-5.

4. Baldani MH, Araújo PFF, Wambier DS, Strosky Ml, Lopes CML. Percepção estética de fluorose dentária entre jovens universitários. Rev Bras Epidemiol. 2008 Dec;11(4):597-607.

5. Peres KG, Latorre MRDO, Peres MA, Traebert J, Panizzi M. Impacto da cárie e da fluorose dentária na satisfação com a aparência e com a mastigação de crianças de 12 anos de idade. Cad Saude Publica. 2003 Jan;19(1):323-30.

6. Levy SM, Warren JJ, Broffitt B, Nielsen B. Factors associated with parents' esthetic perceptions of children's mixed dentition fluorosis and demarcated opacities. Pediatr Dent. 2005 Nov-Dec;27(6):486-92.

7. Martínez-Mier EA, Maupomé G, Soto-Rojas AE, Ureña-Cirett JL, Katz BP, Stookey GK. Development of a questionnaire vary according to sociocultural, psychological, personal and environmental factors, which are affected differently by the disease. We must consider that the emotional environment and physical development of adolescents differ from those of their parents, ${ }^{28} \mathrm{im}$ plying a peculiar perception by adolescents of themselves and the context around them and suggesting that parents and adolescents respond to questionnaires from different perspectives and views on oral health problems.

\section{Conclusions}

The prevalence of dental fluorosis was high in one of the communities studied, but the clinical diagnosis of this condition should not necessarily equate with concern and dissatisfaction with aesthetic appearances among teenagers and their parents.

\section{Acknowledgements}

We would like to thank FUNCAP/CNPq and PRPq at the Universidade Federal de Minas Gerais - UFMG. to measure perceptions of, and concerns derived from, dental fluorosis. Community Dent Health. 2004 Dec;21(4):299-305.

8. Sigurjóns H, Cochran JA, Ketley CE, Holbrook WP, Lennon MA, O'mullane DM. Parental perception of fluorosis among 8 -year-old children living in three communities in Iceland, Ireland and England. Community Dent Oral Epidemiol. 2004 Apr;30 Suppl 1:34-8.

9. Pereiras PM, Silva APA, Zocratto KBF. Fluorose dentária: percepção dos portadores e seus responsáveis. RFO UPF. 2009 Jan;14(1):18-22.

10. Martins CC, Lima-Arsati YB, Paiva SM. Mothers' perception of dental aesthetics in their children. A study in two fluoridated communities. Rev Odonto Cienc. 2009 Jul-Sep;24(3):236-9.

11. Chankanka O, Levy SM, Warren JJ, Chalmers JM. A literature review of aesthetic perceptions of dental fluorosis and relationships with psychosocial aspects/oral health-related quality of life. Community Dent Oral Epidemiol. 2010 Apr;38(2):97109.

12. Furtado GES, Sousa MLR, Barbosa TS, Wada RS, MartínezMier EA, Almeida MEL. Percepção da fluorose dentária e avaliação da concordância entre relatos de pais e filhos: 
validação de um instrumento. Cad Saude Publica. 2012 Ago;28(8):1493-505.

13. Brasil. Ministério da Saúde. Secretaria de Atenção à Saúde. Departamento de Atenção Básica. Coordenação Nacional de Saúde Bucal. Projeto SB Brasil 2003. Condições de saúde bucal da população brasileira 2002-2003: resultados principais [Internet]. Brasília (DF): Ministério da Saúde; 2004 [cited 2012 Aug 20]. Available from http://dtr2001.saude.gov.br/ editora/produtos/livros/pdf/05_0053_M.pdf.

14. World Health Organization. Oral health surveys: basic methods. $4^{\text {th }}$ ed. Geneva: World Health Organization; 1997. 66 p.

15. Secretaria da Saúde do Estado do Ceará. Levantamento epidemiológico em saúde bucal no estado do Ceará - SB Ceará: resultados finais [Internet]. Fortaleza: SESA; 2004 [cited 2012 Jul 20]. 47 p. Available from: http://www.saude.ce.gov. br/index.php/politicas-de-saude/organizacao-de-servicos/ atencao-especializada/44756-saude-bucal.

16. Catani DB, Hugo NF, Cypriano S, Sousa MLR, Cury JA. Relação entre níveis de fluoreto na água de abastecimento público e fluorose dental. Rev Saude Publica. 2007 Oct;41(5):732-9.

17. Brasil. Ministério da Saúde. Secretaria de Atenção à Saúde. Secretaria de Vigilância em Saúde Departamento de Atenção Básica. Coordenação Geral de Saúde Bucal. SB Brasil: pesquisa nacional de saúde bucal 2010 - resultados principais [Internet]. Brasília (DF): Ministério da Saúde; 2011 [cited 2012 Aug 25]. 92 p. Available from: http://189.28.128.100/dab/docs/geral/ projeto_sb2010_relatorio_final.pdf.

18. Moysés SJ, Moysés ST, Allegretti ACV, Argenta M, Werneck R. Fluorose dental: ficção epidemiológica?. Rev Panam Salud Publica. 2002 Nov;12(5):339-46.

19. Menezes LMB, Sousa MLR, Rodrigues LKA, Cury JA. Autopercepção da fluorose pela exposição a flúor pela água e dentifrício. Rev Saude Publica. 2002 Dec;36(6):752-4.

20. Toassi RFC, Abegg C. Fluorose dentária em escolares de um município da serra gaúcha, Rio Grande do Sul, Brasil. Cad Saude Publica. 2005 Mar-Apr;21(2):652-5.
21. Michel-Crosato E, Barbieri DB, Biazevic MG, Correia LD. Condição de saúde bucal e autopercepção de fluorose dental: um estudo de base populacional no Sul do Brasil, 2003. RPG. 2007 Dec;13(4):353-7.

22. Carvalho TS, Kehrle HM, Sampaio FC. Prevalência e severidade de fluorose dentária em escolares da cidade de João Pessoa, PB, Brasil. Braz Oral Res. 2007 Jul-Sep;21(3):198-203.

23. Meneghim MC, Kozlowski FC, Pereira AC, Assaf AV, Tagliaferro EPS. Perception of dental fluorosis and other oral health disorders by 12 -year-old Brazilian children. Int J Paediatr Dent. 2007 May;17(3):205-10.

24. Martins CC, Chalub L, Lima-Arsati YB, Pordeus IA, Paiva, SM. Agreement in the diagnosis of dental fluorosis in central incisors performed by a standardized photographic method and clinical examination. Cad Saude Publica. 2009 May;25(5):1017-24.

25. Teixeira AKM, Menezes LMB, Dias AA, Alencar CHM, Almeida MEL. Análise dos fatores de risco ou de proteção para fluorose dentária em crianças de 6 a 8 anos em Fortaleza, Brasil. Rev Panam Salud Publica. 2010 Dec;28(6):421-8.

26. Hussain J, Hussain I, Sharma KC. Fluoride and health hazards: community perception in a fluorotic area of central Rajasthan (India): an arid environment. Environ Monit Assess. 2010 Mar;162(1-4):1-14

27. Cangussu MCT, Narvai PC, Fernandez RC, Djehizian V. A fluorose dentária no Brasil: uma revisão crítica. Cad Saude Publica. 2002 Jan-Feb;18(1):7-15.

28. Wondwossen F, Astrøm AN, Bardsen A, Bjorvatn K. Perception of dental fluorosis amongst Ethiopian children and their mothers. Acta Odontol Scand. 2003 Apr;61(2):81-6.

29. Shulman JD, Maupomé G, Clark DC, Levy SM. Perceptions of desirable tooth color among parents, dentists and children. J Am Dent Assoc. 2004 May;135(5):595-604.

30. Clark DC, Shulman JD, Maupomé G, Levy SM. Changes in dental fluorosis following the cessation of water fluoridation. Community Dent Oral Epidemiol. 2006 Jun;34(3):197-204. 